\title{
Structural and electrochemical studies of Co oxide films formed by the sol-gel technique
}

\author{
ANNE C. CO, JINGBO LIU \\ Department of Chemistry, University of Calgary, Calgary, AB, Canada T2N1N4 \\ IRINA SEREBRENNIKOVA \\ Energizer, 25225 Detroit Rd, Westlake, OH 44145, USA \\ CHERYL M. ABEL, VIOLA I. BIRSS* \\ Department of Chemistry, University of Calgary, Calgary, AB, Canada T2N1N4 \\ E-mail: birss@ucalgary.ca
}

\begin{abstract}
Two different types of Co oxide films, each having a distinct electrochemical signature correlated with the film drying temperature, were formed using the sol-gel (SG) technique. Two different states of gelation of the film precursor were also explored. Cyclic voltammograms, collected in alkaline solutions for the low temperature films, displayed two pairs of peaks corresponding to the Co(II) to Co(III) and Co(III) to Co(IV) transitions, centered at 1.2 and $1.4 \mathrm{~V}$, respectively, while the high temperature films underwent only the Co(III) to Co(IV) redox process at $1.4 \mathrm{~V}$. The charge densities obtained for the lower temperature films (particle sizes 2-10 nm in diameter) ranged between 40 and $70 \mathrm{mC} / \mathrm{cm}^{2}$; charge densities for the higher temperature films (particle sizes of 5-40 nm), otherwise formed identically, were between 10 and $20 \mathrm{mC} / \mathrm{cm}^{2}$. The more viscous Co oxide gels led to significantly higher charge densities than less viscous gels, as well as greater film stability during electrochemical cycling. Using a wide range of film characterization techniques, it was shown that $\mathrm{Co}$ oxide films formed at $>180^{\circ} \mathrm{C}$ are composed mainly of $\mathrm{Co}_{3} \mathrm{O}_{4}$ spinel, while films formed at $<180^{\circ} \mathrm{C}$ consist predominantly of $\mathrm{CoO}$.

(C) 2005 Springer Science + Business Media, Inc.
\end{abstract}

\section{Introduction}

The electrochemistry of Co and Co oxide in alkaline solutions has been extensively studied due to their numerous practical applications, including as insertion cathodes in Li batteries [1-3], in electrochromic devices [4, 5], as promising electrocatalysts for the oxygen evolution (OER) [6] and reduction (ORR) reactions [7] and in recording media [8]. Recently, great interest has also been shown in the capacitive behavior of Co oxide films [9]. It is also known that the addition of Co to Ni oxide improves the performance of the Ni oxide cathode, in both aqueous and non-aqueous battery applications [10].

Burke et al. [11] and Simpraga et al. [12] have studied Co oxide films prepared by the anodic oxidation of a metallic Co substrate by potential cycling in alkaline solutions. Other methods of preparing these oxide films include cathodic precipitation [10], electron-beam evaporation [13], chemical deposition [14], electrodeposition [15], spray pyrolysis [16], and, most recently, the use of the sol-gel (SG) technique [17-20]. Svegl et al. [17-19] carried out in situ and ex situ spectroelectrochemical investigations of SG-derived $\mathrm{CO}_{3} \mathrm{O}_{4}$ spinel films, cycled in $0.1 \mathrm{LiOH}$.
Spinolo et al. [21] characterized the surface properties of SG formed spinel Co oxide, deposited on a $\mathrm{Ni}$ support. The surface properties of SG formed Co oxide, using $\mathrm{CoCl}_{2}$ as the precursor, were also studied [22], while the capacitive behavior, surface area and pore volume of SG derived Co oxide films have also been examined $[9,23,24]$.

The SG method is becoming an increasingly popular route for the preparation of metal oxides due to its time and energy saving advantages [25, 26]. Increasing attention on SG formed oxides also arises from their highly porous structure and high surface areas, useful for many applications. SG films can be deposited on essentially any substrate, and can be shaped into fibers, powders, monoliths and films [27]. Further, the SG method allows the preparation of a mixture in solution, achieving homogeneity on the molecular scale in the solid product. Importantly, the composition of SG-derived materials can be tailored by varying the ratio of the precursors in solution. In general, SG processing allows the control of the texture, composition, homogeneity, and structural properties of the resulting materials, which, in turn, influence the physical (film thickness, degree of hydration,

* Author to whom correspondence should be addressed. 
etc.) and electrochemical properties of these films $[18,21,28]$.

Our group has previously carried out detailed electrochemical studies of $\mathrm{Ni}$ and $\mathrm{Ni}$-Co oxide films formed by the SG technique [20, 24, 28-30], revealing the many beneficial factors of the presence of Co in these mixed films, while also demonstrating the contribution of Co redox chemistry to their response. In our preliminary work with pure Co oxide SG-formed films [29-31], it was shown that films formed by drying in the range of $200^{\circ} \mathrm{C}$ could exhibit one of two distinct types of cyclic voltammetric $(\mathrm{CV})$ responses. Therefore, a key goal of the present work was to establish the origin and meaning of these two CV signatures. As well, Co sol-gel solutions of differing viscosity have been synthesized and studied here in an attempt to improve the adhesion of the films to the substrate, as well as to enhance the film stability in alkaline solutions.

\section{Experimental procedure}

\subsection{Sol-gel (SG) formed Co oxide film preparation}

\subsubsection{Preparation of Co-containing sol}

The Co oxide sol was prepared as described elsewhere $[30,32]$ i.e., by dissolving $11 \mathrm{~g}$ of $\mathrm{Co}\left(\mathrm{NO}_{3}\right)_{2} \cdot 6 \mathrm{H}_{2} \mathrm{O}$ (Aldrich) in $80 \mathrm{ml}$ of absolute ethanol. The solution was refluxed and stirred continuously for $5 \mathrm{~h}$ on a water bath and then cooled to room temperature over $4 \mathrm{~h}$. A mixture of $80 \mathrm{ml}$ ethyl acetate (BDH) and $1 \mathrm{ml}$ Mazawet $\mathrm{DF}^{\mathrm{TM}}$ nonionic surfactant (PPT Industries) was added to the solution to improve the uniformity of the resulting films. The resulting sol phase, having a viscosity of 7 centistokes, is referred to as SGA (Fig. 1).

SGA was stirred for another $18 \mathrm{~h}$ and heated again for $2 \mathrm{~h}$ at $80^{\circ} \mathrm{C}$ to evaporate the solvent (to $\sim 30-50 \%$ of the initial volume) until a viscosity of ca. 12 centistokes was obtained. This higher viscosity sol-gel phase is referred to as SGB (Fig. 1).

\subsubsection{Deposition of Co oxide film on electrode substrate}

SG derived Co oxide films were then deposited on $\mathrm{Pt}$ foil (99.99\% purity, Johnson-Matthey, Aldrich) or Pt sputter-coated glass substrates, with geometric surface areas ranging between 0.4 and $1 \mathrm{~cm}^{2}$. A dip-coating procedure, in which the substrate was immersed in the sol phase and then withdrawn at a constant rate of 1.2 to $24 \mathrm{~cm} / \mathrm{min}$ to vary the film thickness, was employed. The film was then placed into a pre-heated oven and calcinated between 100 and $300^{\circ} \mathrm{C}$ for 15 to $240 \mathrm{~min}$. The Co oxide films formed from both SGA and SGB were then equilibrated in 0.1 and $1 \mathrm{M} \mathrm{NaOH}$ for 0.5 to $70 \mathrm{~h}$ prior to any electrochemical measurements. Electrochemical data reported in this paper were obtained after equilibrating the film-coated electrodes in $0.1 \mathrm{M}$ $\mathrm{NaOH}$ for $18 \mathrm{~h}$ for SGA and $2 \mathrm{~h}$ for SGB.

\subsection{Film characterization}

2.2.1. Thermal analysis of Co oxide gel

Thermal gravimetric analysis (TGA) and differential scanning calorimetry (DSC) were performed using a NETZSCH STA 449C to examine the thermal behavior of the air dried Co oxide sol. Samples were loaded into an $\mathrm{Al}_{2} \mathrm{O}_{3}$ crucible and purged with high purity nitrogen at $30 \mathrm{~mL} / \mathrm{min}$. The mass and thermal changes were measured as the temperature was increased from 22 to $900^{\circ} \mathrm{C}$ at $5^{\circ} \mathrm{C} / \mathrm{min}$.

\subsubsection{Scanning electron microscopy (SEM) surface morphology studies}

The thickness and surface morphology of the Co oxide SG films were determined by scanning electron microscopy (SEM) by using a Philips/FEI ESEM (Health Sciences Center, University of Calgary) and a JOEL JXA-8200 electron microprobe (Department of Geology and Geophysics, University of Calgary). An accelerating voltage of $20 \mathrm{kV}$ and a high vacuum of

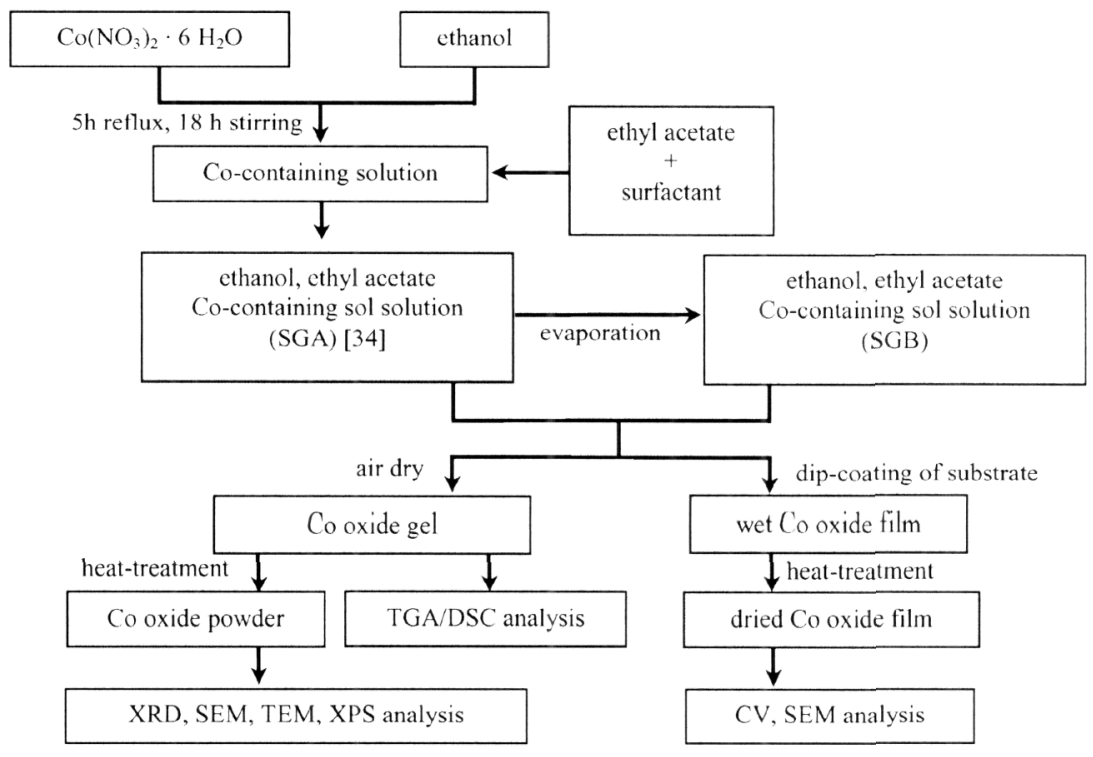

Figure 1 Flowchart showing SG formation and characterization of Co oxide powders and films. 
$2 \times 10^{-4}$ Torr were generally employed. The SG films were mechanically fractured using a diamond blade before mounting them on $\mathrm{Al}$ stubs using conducting carbon tape (E. T. Enterprises). A thin layer of $\mathrm{Au} / \mathrm{Pd}, \mathrm{Pt}$ or $\mathrm{C}$ was sputtered onto the sample to improve surface conductivity. The samples were also tilted in the SEM chamber for a better estimation of the film thicknesses.

\subsubsection{Transmission electron microscopy (TEM) and electron diffraction (ED) analysis}

A Hitachi H-7000 transmission electron microscopy (TEM, Health Sciences Center, University of Calgary) with electron diffraction (ED) capabilities was employed to obtain particle size and phase information about the SG formed Co oxides. Co oxide samples were first sonicated for $60 \mathrm{~min}$ to ensure suspension in ethanol. The suspended samples were then deposited onto the carbon-coated $\mathrm{Cu}$-grid and allowed to dry in air at room temperature for the evaporation of ethanol.

\subsection{4. $X$-ray diffraction (XRD) studies}

$\mathrm{X}$-ray powder diffraction was employed to determine the phase and the average crystallite size of the SG formed Co oxide materials. The XRD patterns were collected using a Rigaku multiflex diffractometer (Department of Geology and Geophysics, University of Calgary), equipped with a $\mathrm{Cu}$ target with an operating voltage and current of $40 \mathrm{kV}$ and $40 \mathrm{~mA}$, respectively. The scanning range was varied between 10 and 70 degrees at a rate of $2 \% \mathrm{~min}$. XRD data were analysed using MDI Jade 6.5 software. The average crystallite size (D, in $\AA$ ), was calculated using the Scherrer equation [33], $\mathrm{D}=\mathrm{K} \lambda / \beta \cos \theta$, where $\mathrm{K}$ is a constant (taken as 0.89), $\lambda$ is the incident radiation wavelength ( $1.5406 \AA$ for $\mathrm{Cu}$ $\mathrm{K} \alpha_{1}$ radiation), $\beta$ is the peak width at half-maximun in units of $2 \theta$ and $\theta$ is the Bragg angle of diffraction.

\subsubsection{X-ray photoelectron spectroscopy (XPS) studies}

Most of the XPS spectra were collected using a Kratos Axis $165 \mathrm{X}$-ray Photoelectron Spectrometer (Alberta Centre for Surface Engineering and Science, University of Alberta) with monochromatized $\mathrm{Al} \mathrm{K} \alpha$ radiation $(1486.6 \mathrm{eV})$ working at $210 \mathrm{~W}$. Some of the XPS spectra were obtained using a VG Scientific ESCALAB220IXL (Chemical Institute, Chinese Academy of Science, China) photoelectron spectrometer using monochromatic $\mathrm{Al} \mathrm{K} \alpha$ radiation (1486.6 eV), with an operating $\mathrm{X}$-ray power of $300 \mathrm{~W}$. The working pressure in both systems was lower than $10^{-7} \mathrm{~Pa}$. XPS spectra were recorded in the constant analyzer energy (CAE)-mode.

Using the Kratos Axis 165, extended spectra (survey) were collected in the range of 0 to $1196 \mathrm{eV}$ with a pass energy of $160 \mathrm{eV}, 0.4 \mathrm{eV} \mathrm{step}^{-1}$ and $100 \mathrm{~s} \mathrm{step}^{-1}$. Detailed spectra were recorded for the Co $2 p, O 1 s$, and $\mathrm{C} 1 \mathrm{~s}$ regions with $10 \mathrm{eV}, 10 \mathrm{eV}$ and $20 \mathrm{eV}$ pass energy, respectively and a data collection rate of $0.1 \mathrm{eV} \mathrm{step}^{-1}$ and $200 \mathrm{~s} \mathrm{step}^{-1}$. A linear background correction was applied to the raw spectra to obtain quantitative ratios of the elements analyzed. Depth profiles of the different elements were carried out by $\mathrm{Ar}^{+}$sputtering at $3 \mathrm{keV}$ with an Ar pressure of $5.5 \times 10^{-7}$ torr. No charging was observed for the reference standards of $\mathrm{CoO}$ and $\mathrm{Co}_{3} \mathrm{O}_{4}$. However, charging problems related to the lowtemperature SGA and SGB films were corrected for by comparing the binding energy ( $\mathrm{BE}$ ) of the observed $\mathrm{C}$ $1 \mathrm{~s}$ peak to the reported value of $284.9 \mathrm{eV}[34,35]$.

\subsection{Electrochemical studies}

The working electrodes (WE) employed in this work were SG-formed Co oxide films coated on a Pt substrate, as described earlier. The counter electrode (CE) was a large area (ca. $0.7 \mathrm{~cm}^{2}$ ) Pt gauze, while the reversible hydrogen electrode (RHE), separated from the WE cell compartment by a closed wet stopcock and a Luggin capillary, was used as the reference electrode (RE). All potentials quoted in this paper are referred to the RHE. Cyclic voltammetry (CV) experiments were carried out using a Vanostat HA-301 potentiostat equipped with PowerLab Chart v4.0 (ADInstruments) for data acquisition or an EG\&G PARC 173 potentiostat and EG\&G PARC 175 programmer equipped with a Hewlett-Packard 7044 X-Y recorder. Solutions of 0.1 $\mathrm{M} \mathrm{NaOH}$ were deaerated by purging with $\mathrm{N}_{2}$ gas for 15 min before recording the CVs. Triply distilled water was used to prepare all solutions and all electrochemical experiments were carried out at room temperature, $22 \pm 2^{\circ} \mathrm{C}$.

\section{Results and discussion}

\subsection{TGA-DSC analysis}

The TGA and corresponding DSC data for a Co oxide $\mathrm{SGB}$, air-dried at room temperature, as well as for the $\mathrm{Co}\left(\mathrm{NO}_{3}\right)_{2} \cdot 6 \mathrm{H}_{2} \mathrm{O}$ starting material (Fig. 2), show slight differences in their decomposition behavior. The mass loss seen for the $\mathrm{Co}\left(\mathrm{NO}_{3}\right)_{2} \cdot 6 \mathrm{H}_{2} \mathrm{O}$ starting material occurs in five main stages. An initial mass loss of $\sim 14 \%$ between 25 and $100^{\circ} \mathrm{C}$ is attributed to the loss of two water molecules $(\sim 12.4 \%)$ from the hexahydrated starting material. This is followed by two separate $\sim 13 \%$ mass losses between 100 to $150^{\circ} \mathrm{C}$ and 150 to $200^{\circ} \mathrm{C}$, each attributed to a further loss of two water molecules bound to the Co centre. A $\sim 35 \%$ mass loss between 200 and $275^{\circ} \mathrm{C}$ suggests the decomposition of the nitrate species (e.g. two $\mathrm{NO}_{2} \sim 32 \%$ ), forming $\mathrm{Co}_{3} \mathrm{O}_{4}$. The final mass loss of $\sim 3 \%$ at 750 to $800^{\circ} \mathrm{C}$ was attributed to the reaction of some Co oxide in contact with the $\mathrm{Al}_{2} \mathrm{O}_{3}$ heating pans, likely forming the blue cubic $\mathrm{CoAl}_{2} \mathrm{O}_{4}$ compound at high temperatures.

In comparison with the starting material, the TGA data of the Co SG compounds were more difficult to analyze, due to the anticipated "polymeric" nature of the Co oxide network. Based on the assumption that only $\mathrm{Co}_{3} \mathrm{O}_{4}$ is present at temperatures $>300^{\circ} \mathrm{C}$ (based on the XRD, ED and XPS data of the $300^{\circ} \mathrm{C}$ dried material-see below), and assuming all Co present in the $\mathrm{SG}$ material is converted to $\mathrm{Co}_{3} \mathrm{O}_{4}$ at $300^{\circ} \mathrm{C}$, a possible decomposition mechanism can be deduced. As 


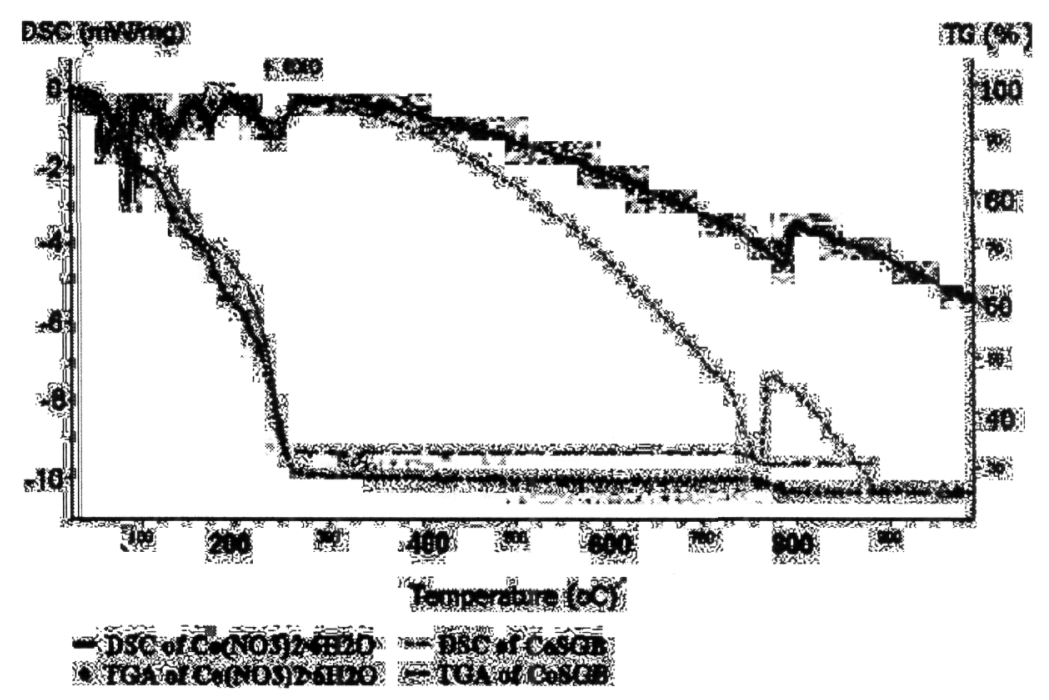

Figure 2 TGA/DSC data for SG formed Co oxide gel (SGB), initially air-dried at room temperature, heated at $5 \mathrm{~K} / \mathrm{min}$ in N2 flowing at $30 \mathrm{~mL} / \mathrm{min}$.

the SG network is likely a hydrated, polymeric system, each major mass loss region may be due to either a single step or a combination of steps.

However, it can be concluded that $0.4 \mathrm{mg}(31 \%$ of initial mass of $1.333 \mathrm{mg} \mathrm{SGB}$ ) of $\mathrm{Co}_{3} \mathrm{O}_{4}$ was formed at $300^{\circ} \mathrm{C}$. The mass loss seen in each thermal region were assigned as follows. An initial mass loss of $\sim 0.13 \mathrm{mg}$ (about 10 mass\%) between 25 to $75^{\circ} \mathrm{C}$, which is accompanied by a broad endothermic peak, is attributed to the evaporation of ethanol or ethyl acetate trapped inside the pores of the air dried Co SG network. This is followed by a major mass loss of $0.18 \mathrm{mg}(\sim 25 \%)$ between 100 and $150^{\circ} \mathrm{C}$, corresponding to three endothermic peaks very similar to those of the starting material, attributed to the removal of bonded water from the Co centre. The removal of two water molecules would result in a $0.19 \mathrm{mg}$ mass loss, assuming a $2: 1 \mathrm{H}_{2} \mathrm{O}$ :Co ratio.

The region between 150 and $200^{\circ} \mathrm{C}$, with a mass loss of $\sim 0.18 \mathrm{mg}$, is referred to as the intermediate region. The DSC behavior in this region differs significantly from that of the starting material and hence the mass losses are more difficult to interpret. It is possible that this mass change may be due to the removal of two oxygens per Co unit, either from the conversion of Co hydroxide to Co oxide or from nitrate decomposition, which is then followed by the removal of nitrite in the next step. The removal of two oxygens would result in a $0.17 \mathrm{mg}$ mass loss, assuming a 2:1 O:Co ratio.

A major mass loss of $0.42 \mathrm{mg}$ between 200 and $260^{\circ} \mathrm{C}$, accompanied by a broad endothermic peak, is attributed to nitrate decomposition, releasing $\mathrm{NO}_{2}$ and forming $\mathrm{CO}_{3} \mathrm{O}_{4}$, where a $2: 1 \mathrm{NO}_{2}$ :Co ratio yields a 0.49 mg mass loss. The DSC data for SGB also matches the DSC pattern assigned to decomposition of the starting material. The formation of spinel type $\mathrm{Co}_{3} \mathrm{O}_{4}$ at temperatures of $\sim 200^{\circ} \mathrm{C}$ is occurring at a lower temperature than reported earlier for $\mathrm{SG}$ formed $\mathrm{Co}_{3} \mathrm{O}_{4}[17-19,22]$. The final mass loss of $0.02 \mathrm{mg}(\sim 3 \%)$ at $740-760^{\circ} \mathrm{C}$, accompanied by a marked endothermic peak, is again attributed to the formation of a blue cubic $\mathrm{CoAl}_{2} \mathrm{O}_{4}$ by reaction of $\mathrm{Co}$ oxide with the $\mathrm{Al}_{2} \mathrm{O}_{3}$ pans. Very similar TGA/DSC patters were observed for SGA films, indicating that these films differ only in their viscosity.

\subsection{Microstructural and compositional analysis of SG-formed Co oxide films 3.2.1. SEM analysis}

A typical SEM image of a SGB Co oxide film, dried at $165^{\circ} \mathrm{C}$ for $2 \mathrm{~h}$ on a Pt substrate, is shown in Fig. 3. The microstructure shows that the films are porous. Heat treatment during the preparation of these films results in the loss of water and organic residues, as well as the sintering of particles. In addition, the high vacuum of the SEM will result in further evaporation of the solvent, and thus cracks are observed due to film shrinkage from both the pre-heat treatment and the SEM environment (Fig. 3b)

It is widely accepted [32] that variables such as substrate withdrawal rate from the sol and drying temperature affect SG film thickness, which can then influence film redox kinetics and charge densities, consistent with our previous study of Co-Ni oxide based materials [28]. Indeed, the measurement of SG-formed Co oxide film (SGA) weight as a function of withdrawal rate (Fig. 4) shows that the amount of film deposited on the substrate is proportional to the square root of withdrawal rate, as expected for sol-gel derived films [32]. It is also thought that longer drying times and higher heating temperatures will form thinner layers due to film shrinkage.

For these reasons, efforts were made to measure the thickness of the SG formed films from the edge of film fragments at crack sites (Fig. 3b). However, these films were found to be quite non-uniform, even though this is not obvious in Fig. 3b. While the SG film thickness was measured in several locations (typically more than 6 sites per specimen), the results showed a range of error from $\pm 15-40 \%$ vs. the mean for both SGA and SGB films. It can therefore only be concluded from this work that our SG-derived Co oxide films are between 200 and 


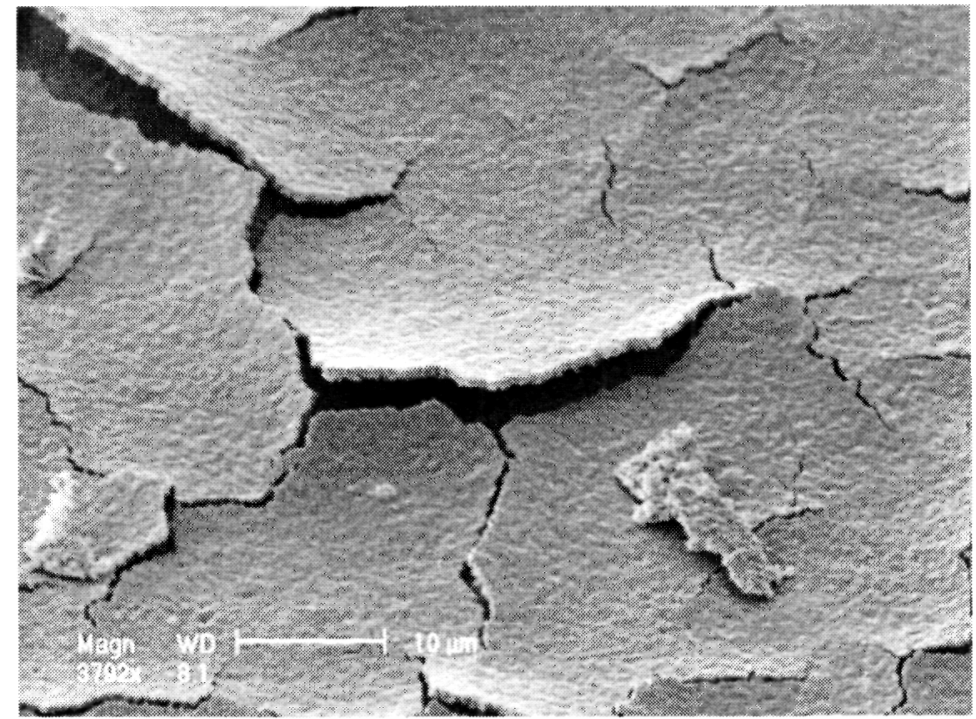

(a)

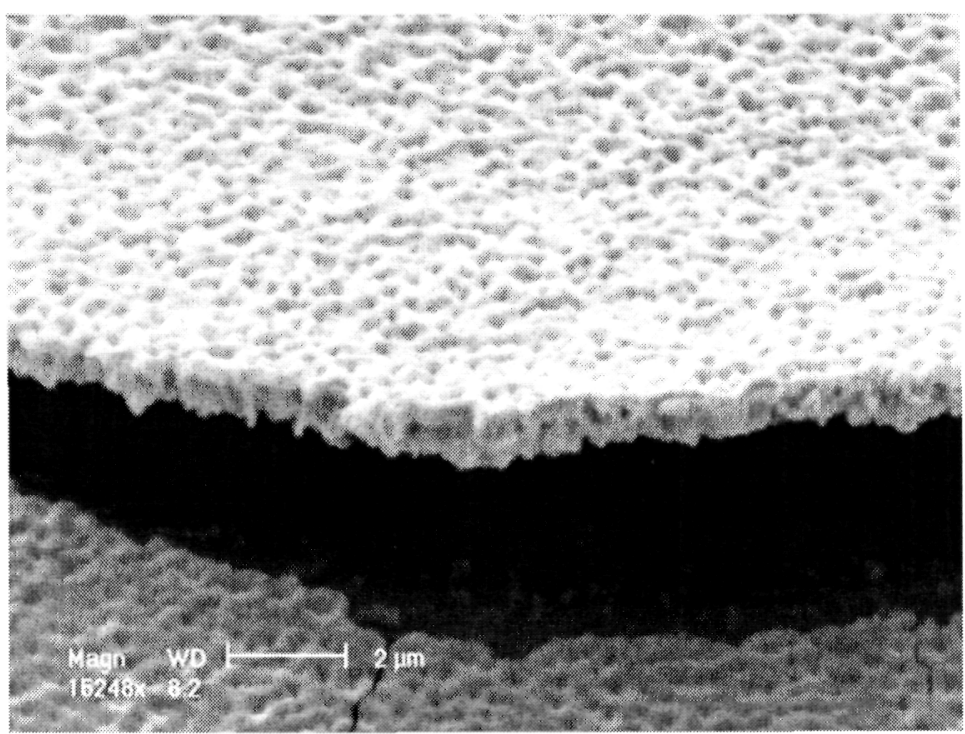

(b)

Figure 3 SEM images of SGB formed Co oxide film withdrawn at $1.2 \mathrm{~cm} / \mathrm{min}$ and dried in air at $165 \mathrm{C}$ for $120 \mathrm{~min}$. (b) is a higher magnification image of the centre of image in (a).

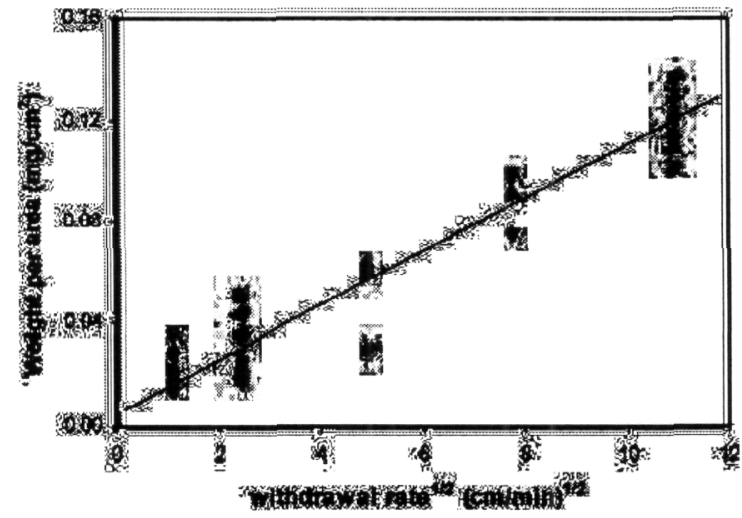

Figure 4 Effect of withdrawal rate on film weight for SGA films, formed by withdrawing of Pt substrate at 1.2 to $120 \mathrm{~cm} / \mathrm{min}$ from the sol and drying at $175 \mathrm{C}$ in air for $120 \mathrm{~min}$.
$1200 \mathrm{~nm}$ in thickness and that no real trends between film thickness and withdrawal rate, drying temperature or time, can be discerned.

Figs 5 and 6 shows the back scattered electron (BSE) images of SGA and SGB films, respectively, after exposure to electrochemical cycling. The darker areas represent the Co oxide film and the lighter background reflects the back-scattered electrons from the Pt substrate. It is observed that, on average, SGA films appear to be thinner and more uniform than SGB films after electrochemical cycling. It is also observed that high temperature dried SGA and SGB films (Figs 5b and $6 \mathrm{~b}$ ) are more uniform than the low temperature films (Figs 5a and 6a). Furthermore, the low temperature dried SGB films (Fig. 6a) are less uniform than SGA films (Fig. 5a), showing preferential film loss in certain regions, resulting in uneven films, especially 


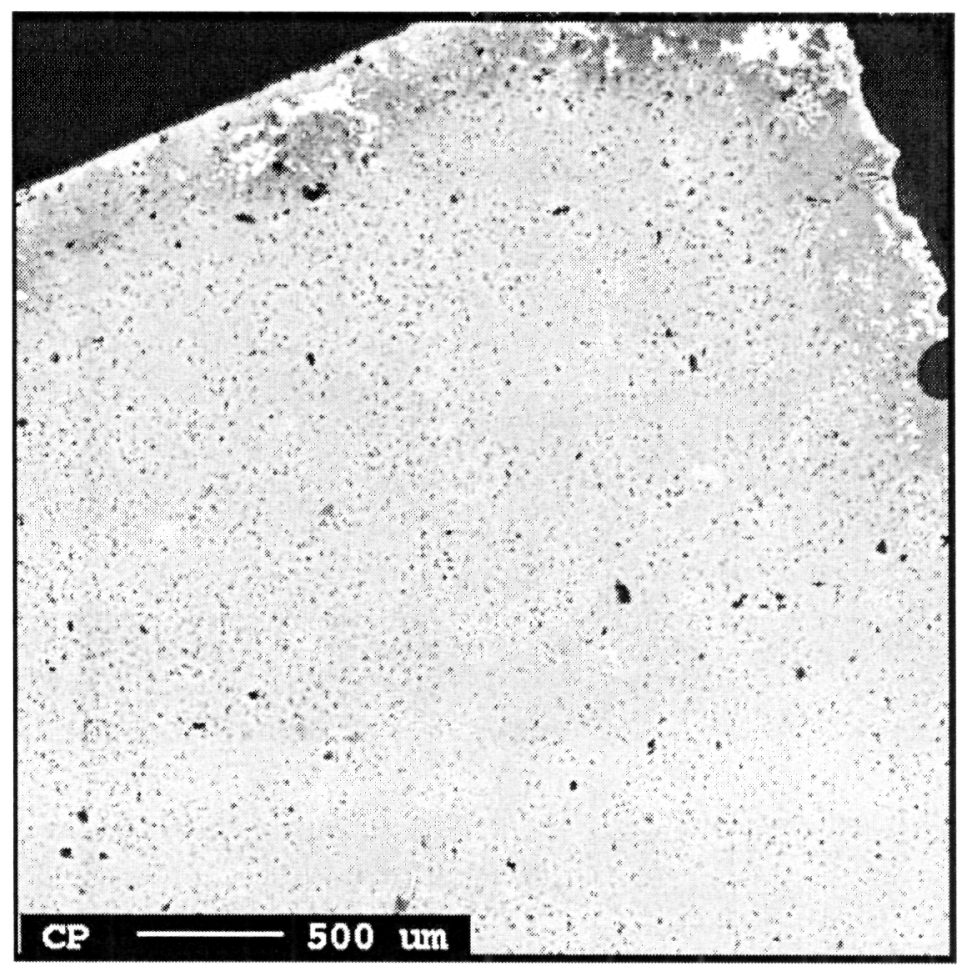

(a)

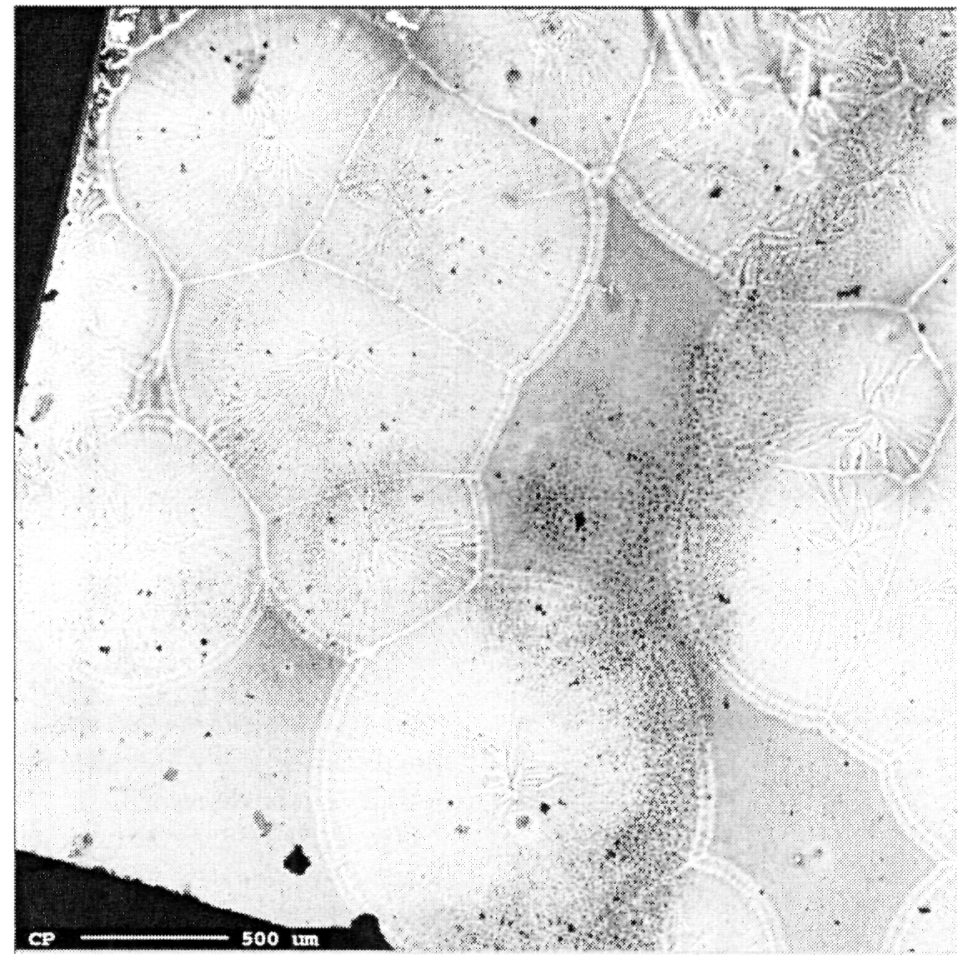

(b)

Figure 5 Back-scattered electron SEM image of SGA formed Co oxide film formed by withdrawal of Pt at $6 \mathrm{~cm} / \mathrm{min}$ and dried at (a) $175 \mathrm{C}$ and (b) $300 \mathrm{C}$ for $15 \mathrm{~min}$ after electrochemical experiments in $0.1 \mathrm{M} \mathrm{NaOH}$.

after electrochemical cycling. However, the electrochemically active charge obtained for these films will be shown below (Section 3.3) to be higher for SGB vs. SGA films.

\subsubsection{TEM and electron diffraction (ED)} analysis of SG-derived Co oxide films

TEM analysis shows that the shape of the SGA and SGB formed Co oxide particles, dried at between 100 


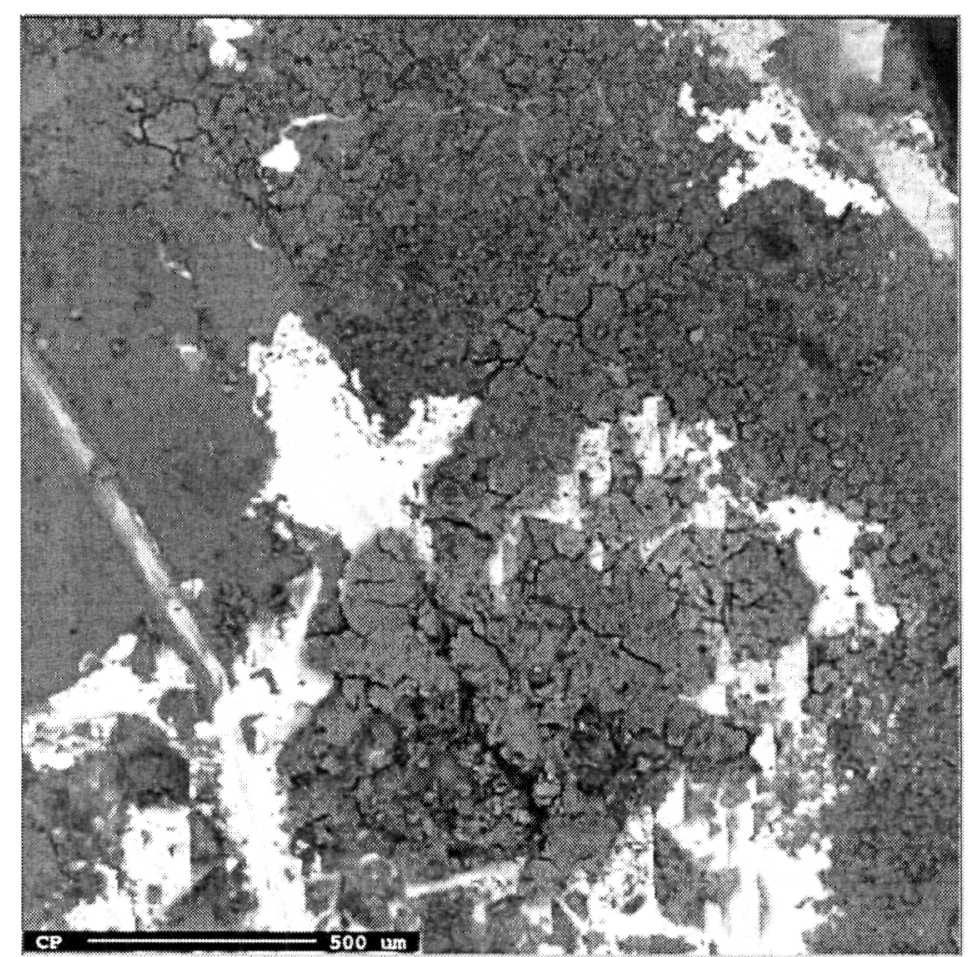

(a)

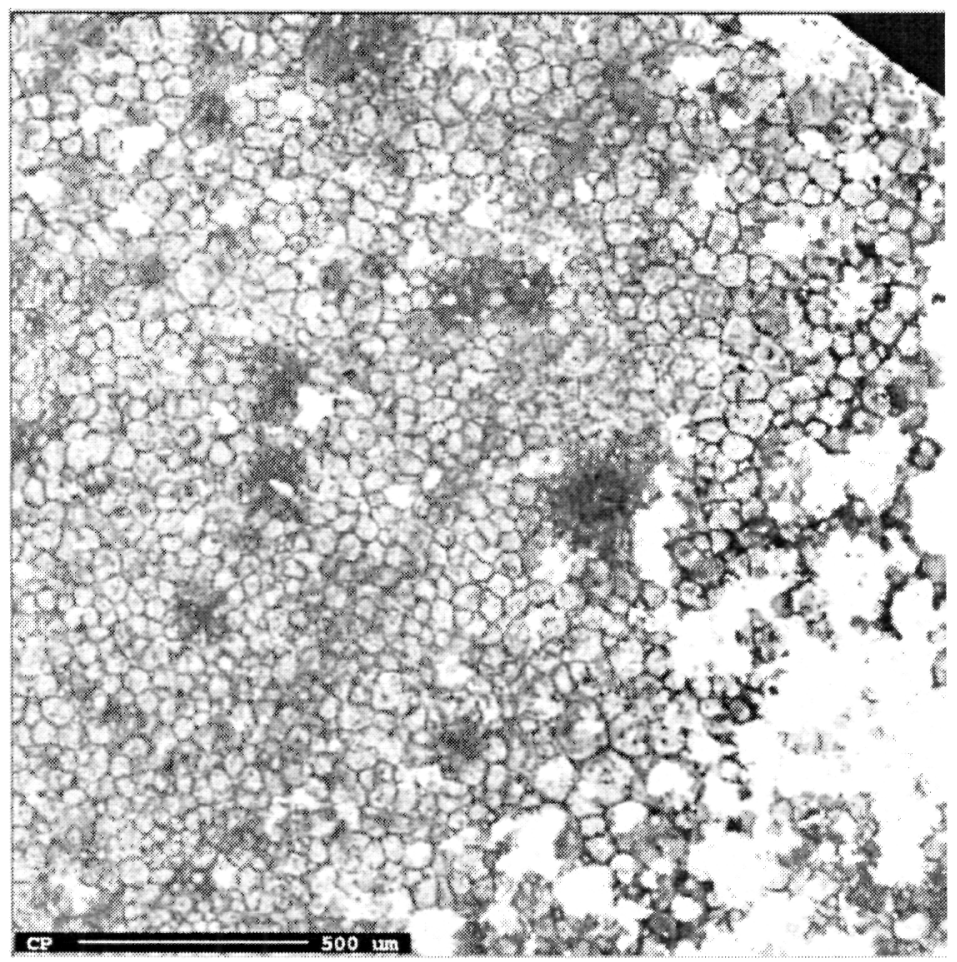

(b)

Figure 6 Back-scattered electron SEM image of SGB formed Co oxide film formed by withdrawal of Pt at $1.2 \mathrm{~cm} / \mathrm{min}$ and dried at (a) $175 \mathrm{C}$ and (b) $300 \mathrm{C}$ for $120 \mathrm{~min}$ after electrochemical experiments in $0.1 \mathrm{M} \mathrm{NaOH}$

and $400^{\circ} \mathrm{C}$, is mainly pseudo-spherical. Well-defined particles are barely observed for the films formed at lower temperatures than this (Fig. 7). On the other hand, Co oxide particles formed at higher temperatures are nicely resolved, with a narrow size distribution ranging from 3 to 6 and 4 to $10 \mathrm{~nm}$ for particles formed at $300^{\circ} \mathrm{C}$ from SGA (dried for $15 \mathrm{~min}$ ) and SGB (dried for $120 \mathrm{~min}$ ), respectively (Fig. 8). Listed in Table I are the particle sizes of SG-derived Co oxides, as obtained from TEM analysis, showing that they increase with 


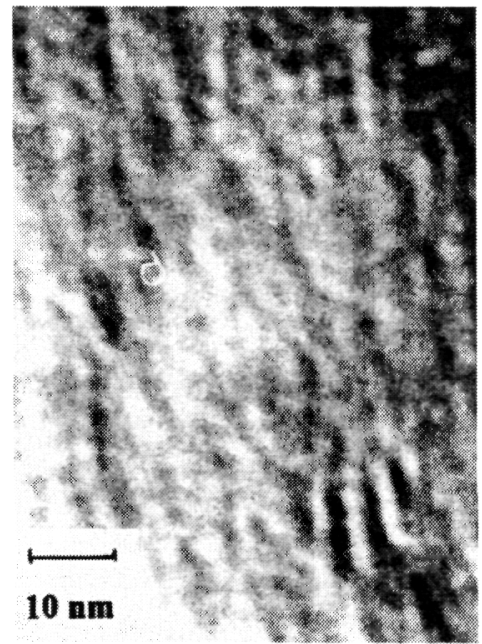

(a)
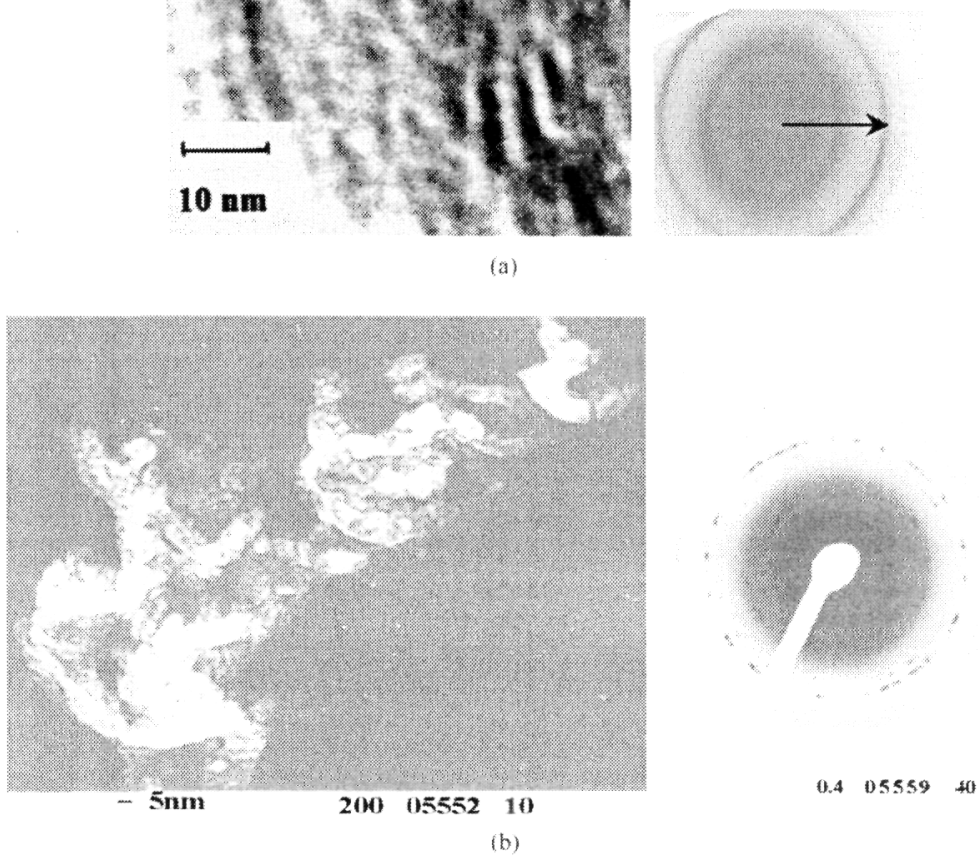

Figure 7 TEM images and corresponding ED patterns for low temperature SG-derived Co oxide films (a) SGA dried at $100 \mathrm{C}$ for 15 min and (b) $\mathrm{SGB}$ dried at $165 \mathrm{C}$ for $120 \mathrm{~min}$.

drying temperature, likely due to sintering effects [27]. Analysis of the TEM images also shows that the Co oxide particles derived from SGB are, on average, $2 \times$ or more the size of SGA derived particles. While the time of drying may also affect particle size, the results for $300^{\circ} \mathrm{C}$ dried SGB ( 2 h of drying), as compared to SGA (15 min drying time), show only a minor difference in the particle size.

The particle size observed for SGB was comparable to those obtained using a Co sulphate derived sol-gel synthesis [19], from which $\mathrm{Co}_{3} \mathrm{O}_{4}$ particles were re-

T A B LE I Average particle size of SGA and SGB Co oxide, as obtained from TEM analysis

\begin{tabular}{lcc}
\hline $\begin{array}{l}\text { Drying } \\
\text { temperature ( C) }\end{array}$ & $\begin{array}{l}\text { SGA particle } \\
\text { size }(\mathrm{nm})\end{array}$ & $\begin{array}{l}\text { SGB particle } \\
\text { size }(\mathrm{nm})\end{array}$ \\
\hline 100 & $2-3$ & - \\
150 & $3-5$ & - \\
175 & & $6-10$ \\
200 & $4-7$ & $10-16$ \\
300 & $3-6$ & $20-40$ \\
400 & $4-9$ & $7-14$ \\
600 & $15-20$ & - \\
\hline
\end{tabular}

Drying time for SGA and SGB was 15 and $120 \mathrm{~min}$, respectively. An average of at least 20 particles were used to obtain particle size. ported to be 20 and $40 \mathrm{~nm}$ in diameter after heat treatment at 300 and $500^{\circ} \mathrm{C}$, respectively. However, the particle sizes obtained from SG derived preparation procedures are significantly smaller than for oxides formed by heat treatment of a Co alloy at $1000^{\circ} \mathrm{C} \mathrm{[36],} \mathrm{where}$ the $\mathrm{CoO}$ particles were reported to range from 100 to $200 \mathrm{~nm}$ in diameter.

The selected area electron diffraction (ED) patterns for Co oxide deposited on a $\mathrm{Cu}$ grid yield well-defined and continuous ring patterns for the high temperature films, characteristic of polycrystalline phases [37, 38] (Fig. 8). A comparison of inter-planar spacings (dspacing) of the SG films formed at 300 and $400^{\circ} \mathrm{C}$ to the JCPDS diffraction database shows a good match with the spinel $\mathrm{Co}_{3} \mathrm{O}_{4}$ oxide [39] (Table II). The particle size and the diffraction index obtained for the SG-formed Co oxide films are similar to those reported by Yang et al. [37] after the hydrothermal oxidation of $\mathrm{Co}(\mathrm{OH})_{2}$ gel at $180^{\circ} \mathrm{C}$ for $2 \mathrm{~h}$ to form $\mathrm{Co}_{3} \mathrm{O}_{4}$, with particle sizes being less than $12 \mathrm{~nm}$, compared to the 4-7 nm and 10-16 nm particle diameters obtained for SGA (dried for $15 \mathrm{~min}$ ) and SGB films (dried for $120 \mathrm{~min}$ at $200^{\circ} \mathrm{C}$ in air), respectively,.

The films formed at the lower temperature of $175^{\circ} \mathrm{C}$, on the other hand, show a very simple diffuse pattern 

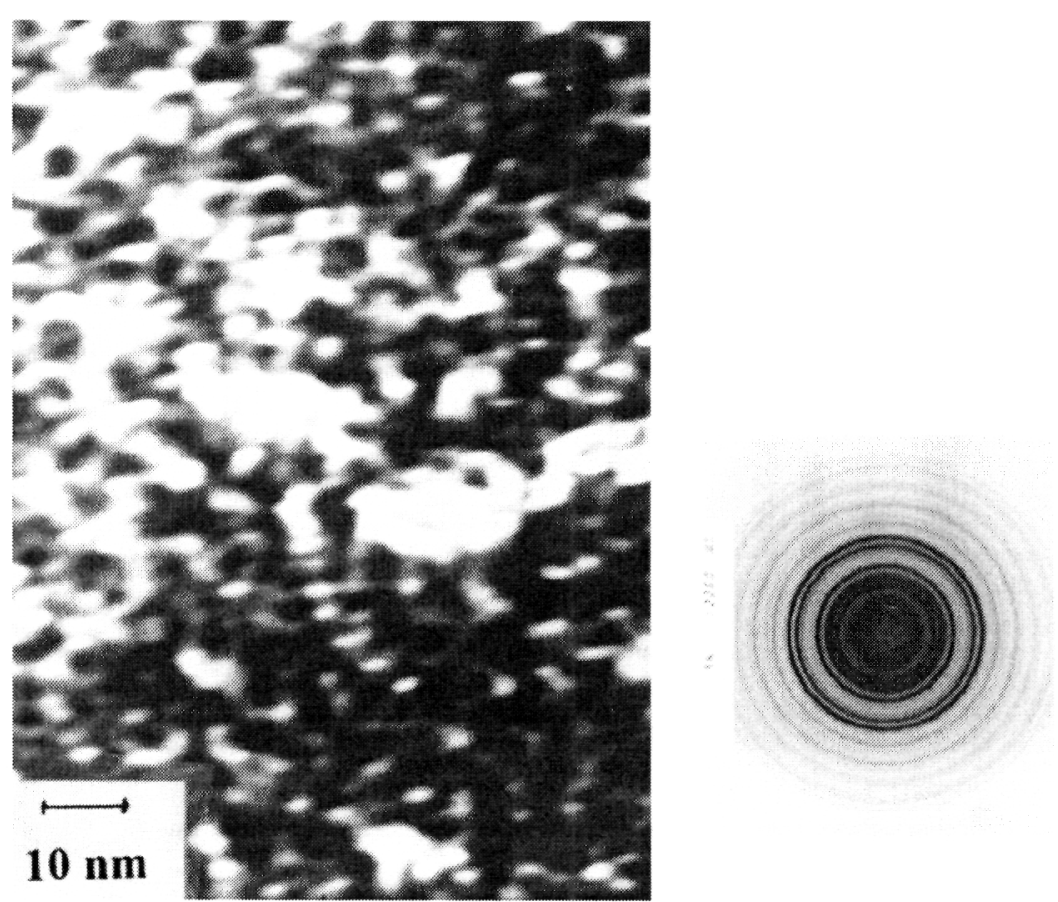

(a)
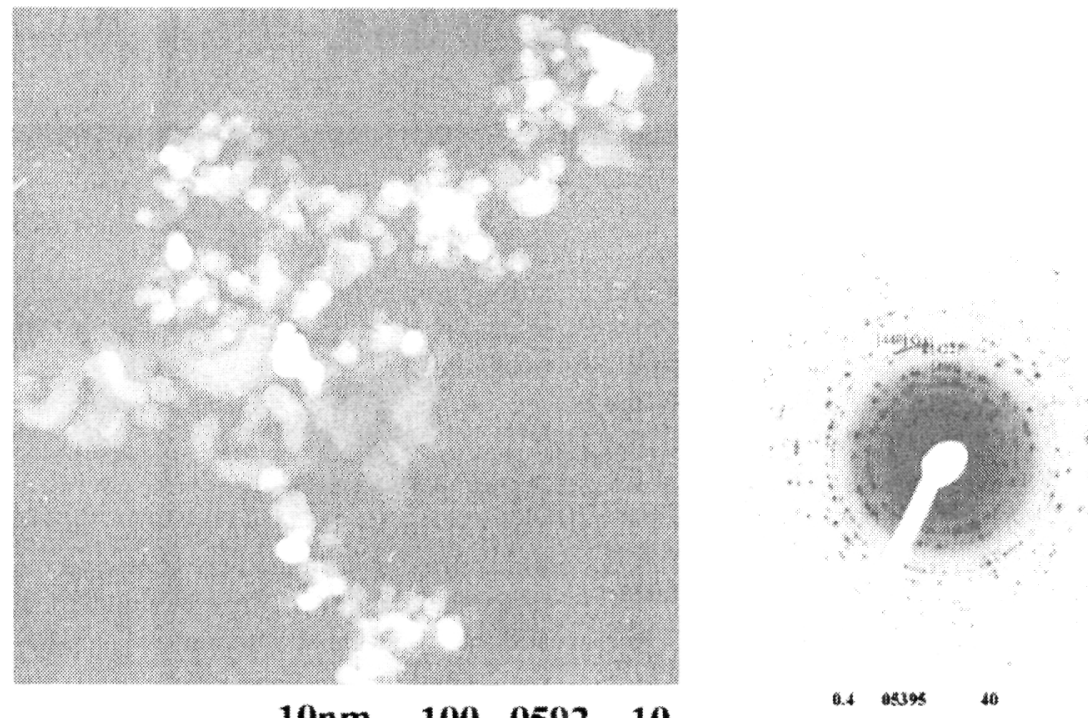

(b)

Figure 8 TEM image and the corresponding ED patterns for high temperature SG-derived Co oxide films (a) SGA dried at 300 C for 15 min and (b) $\mathrm{SGB}$ dried at $300 \mathrm{C}$ for $120 \mathrm{~min}$.

(Fig. 7), likely due to the poor crystallinity of the SG formed film, believed to contain both $\mathrm{CoO}$ and possibly some $\mathrm{Co}\left(\mathrm{NO}_{3}\right)_{2}$ starting material. At these low drying temperatures, some water and organic compounds may also still be trapped within the pores. Thus, in the high vacuum of the TEM chamber, the films will become dehydrated, resulting in a lack of physical and chemical stability, which may also explain the diffuse ED patterns seen at these lower drying temperatures.

\subsection{3. $X R D$ analysis}

The XRD patterns obtained for SGB formed Co oxide, calcined at 175 and $300^{\circ} \mathrm{C}$ for $120 \mathrm{~min}$, are shown in
Figs 9 and 10, respectively. Characteristic lines corresponding to $\mathrm{CO}_{3} \mathrm{O}_{4}$ spinel (JCPDS 42-1467) were observed for $\mathrm{SG}$ formed Co oxide films treated at $300^{\circ} \mathrm{C}$. The average crystallite size calculated from the Scherrer equation [40] ranged from 20 to $40 \mathrm{~nm}$ for the $300^{\circ} \mathrm{C}$ films. These values for SGB generally agree with the size of the nanoparticles seen in the TEM images (Fig. 8) and are similar to those reported previously [17-19] for $\mathrm{SG} \mathrm{Co}_{3} \mathrm{O}_{4}$ formed by heat treatment of a Co sulfate precursor to $300^{\circ} \mathrm{C}$ for $30 \mathrm{~min}$. Barrera $\mathrm{et} \mathrm{al}$. [22] reported the formation of $\mathrm{Co}_{3} \mathrm{O}_{4}$ by heating a $\mathrm{Co}$ acetate sol-gel to $450^{\circ} \mathrm{C}$ for $20 \mathrm{~min}$. The crystallite sizes were ca. $9 \mathrm{~nm}$, slightly smaller than seen in our results. 


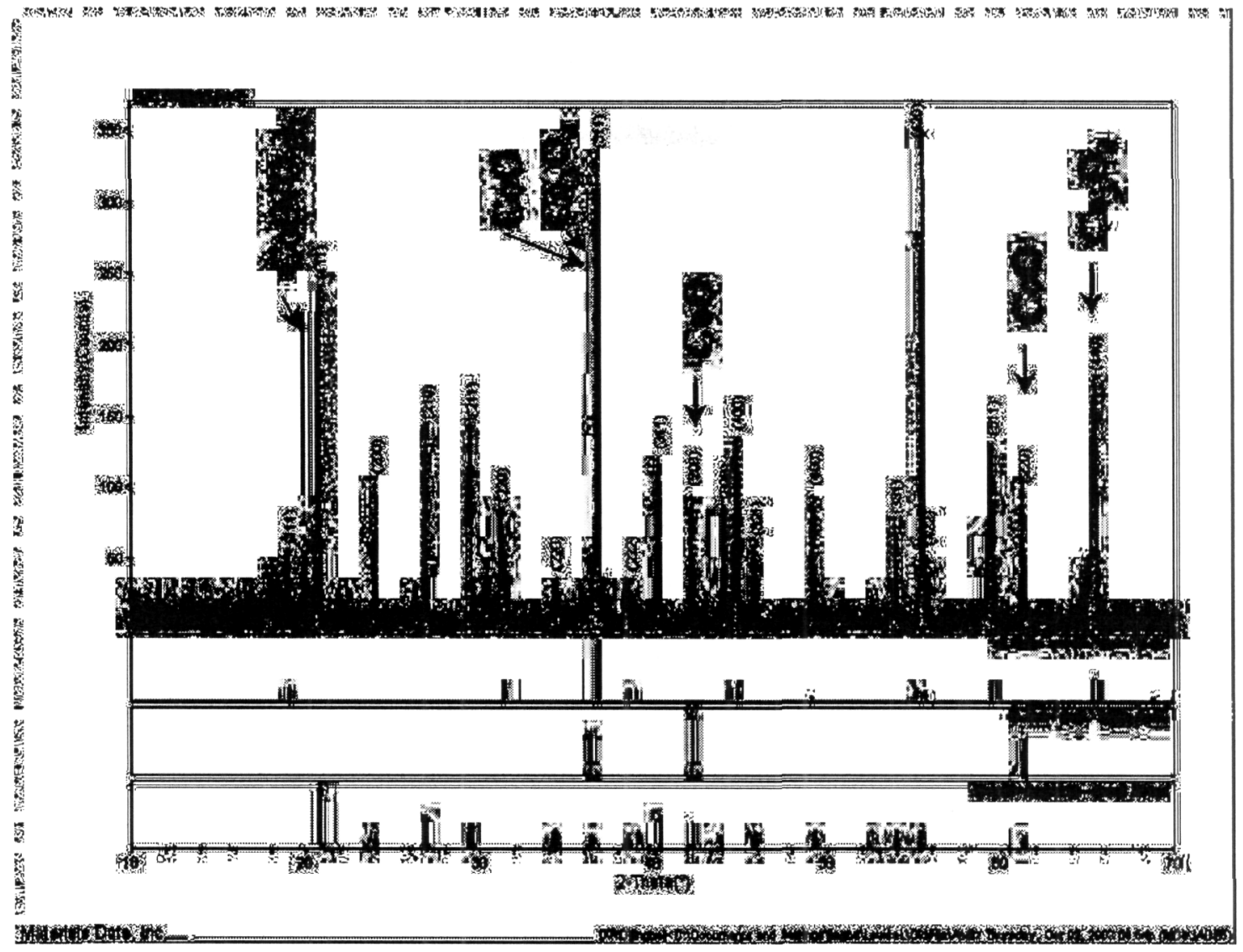

Figure 9 Powder XRD pattern of SGB dried at $175 \mathrm{C}$ for $2 \mathrm{~h}$.

The splitting of the peak at $37^{\circ}$ for both the 175 and $300^{\circ} \mathrm{C}$ (Figs 9 and 10 ) dried films may be due to a lattice distortion from the cubic to tetragonal unit cell.

As opposed to the nicely matched XRD patterns for films formed at $300^{\circ} \mathrm{C}$, it was a challenge matching the XRD data obtained for SG Co oxide powders or films formed below $175^{\circ} \mathrm{C}$ to the database. The XRD pattern for a SG Co oxide formed at $175^{\circ} \mathrm{C}$, as shown in Fig. 9, suggests a mixture of $\mathrm{Co}\left(\mathrm{NO}_{3}\right)_{2}$ starting material, $\mathrm{CoO}$ and $\mathrm{CO}_{3} \mathrm{O}_{4}$. In most cases, films or powders formed at $<175^{\circ} \mathrm{C}$ display a mainly amorphous pattern, which may be due to the very small, $<3 \mathrm{~nm}$ particles, as shown in the TEM image (Fig. 7). The presence of some $\mathrm{CO}_{3} \mathrm{O}_{4}$ may indicate that part of the sample may have experienced temperatures very close to the tran-

TABLE II Comparison of selected area electron diffraction ring patterns of Co oxide SGB films dried at $300 \mathrm{C}$ with the JCPDS diffraction pattern for $\mathrm{CO}_{3} \mathrm{O}_{4}$ polycrystals

\begin{tabular}{lllll}
\hline $\begin{array}{l}\text { Radii } \\
(\mathrm{cm})\end{array}$ & $\begin{array}{l}\text { Experimental } \\
d \text {-spacing }(\AA)\end{array}$ & $\begin{array}{l}\text { JCPDS } d \text {-spacing } \\
(\AA) \text { for } \mathrm{C0}_{3} \mathrm{O}_{4}\end{array}$ & hkl & $\begin{array}{l}\text { Ratio of } \\
d_{\text {exper }} / d_{\text {JCPISS }}\end{array}$ \\
\hline 0.625 & 2.87 & 2.860 & 220 & 1.00 \\
0.375 & 2.44 & 2.438 & 310 & 1.01 \\
0.88 & 2.04 & 2.021 & 400 & 1.01 \\
1.09 & 1.65 & 1.6505 & 442 & 0.999 \\
1.15 & 1.56 & 1.5605 & 511 & 1.00 \\
1.25 & 1.44 & 1.4293 & 440 & 1.01 \\
1.415 & 1.27 & 1.2788 & 620 & 0.993 \\
\hline
\end{tabular}

sition temperature of $\sim 200^{\circ} \mathrm{C}$. Analysis of films dried at the lower temperatures of 100 and $150^{\circ} \mathrm{C}$ showed no evidence of $\mathrm{Co}_{3} \mathrm{O}_{4}$.

\subsubsection{XPS analysis}

The Co $2 p$ XPS spectra of SGA and SGB Co oxide films, dried at 175 and $300^{\circ} \mathrm{C}$, and of $\mathrm{CO}_{3} \mathrm{O}_{4}$ and $\mathrm{CoO}$ reference standards (Figs 11 and 12), were collected and their energies compared [41]. Table III shows the $\mathrm{Co} 2 \mathrm{p}$ and $\mathrm{O} 1 \mathrm{~s}$ binding energy (BE) for the $\mathrm{CoO}$ and $\mathrm{Co}_{3} \mathrm{O}_{4}$ standards, the $150^{\circ} \mathrm{C}$ dried SGA and SGB films, and the $300^{\circ} \mathrm{C} \mathrm{SGB}$ films. The peaks at 781 and $797 \mathrm{eV}$

TABLE III Co $2 \mathrm{p}$ and $\mathrm{O} 1 \mathrm{~s}$ binding energy (eV) of $\mathrm{CoO}$ and $\mathrm{CO}_{3} \mathrm{O}_{4}$ reference standard and SG derived $150 \mathrm{C}$ film (dried for $30 \mathrm{~min}$ ) and $300 \mathrm{C}$ film (dried for $120 \mathrm{~min}$ ) obtained from XPS data

\begin{tabular}{|c|c|c|c|c|c|c|}
\hline \multirow[b]{2}{*}{ Standard } & \multirow[t]{2}{*}{$\operatorname{Co} 2 \mathrm{p}_{3 / 2}$} & \multirow[t]{2}{*}{$\begin{array}{l}\text { Co } 2 \mathrm{p}_{3} / 2 \\
\text { shake-up }\end{array}$} & \multirow[t]{2}{*}{$\operatorname{Co} 2 p_{1 / 2}$} & \multirow[t]{2}{*}{$\begin{array}{l}\text { Co } 2 \mathrm{p}_{1 / 2} \\
\text { shake-up }\end{array}$} & \multicolumn{2}{|c|}{ O 1s } \\
\hline & & & & & & \\
\hline $\mathrm{CoO}$ & 780.6 & 786.6 & 796.4 & 803 & 529.8 & 531.8 \\
\hline $\mathrm{CO}_{3} \mathrm{O}_{4}$ & 782.4 & 790 & 797.5 & 805.9 & 529.8 & 532.5 \\
\hline $100 \mathrm{C}$ & & & & & & \\
\hline SG A & 781.3 & 786.6 & 797.2 & 803 & 532.3 & \\
\hline SG B & 781.4 & 786.6 & 797.4 & 803.2 & 532.1 & 532.8 \\
\hline $300 \mathrm{C}$ & & & & & & \\
\hline SG B & 780.3 & & 795.7 & 804.7 & & \\
\hline
\end{tabular}




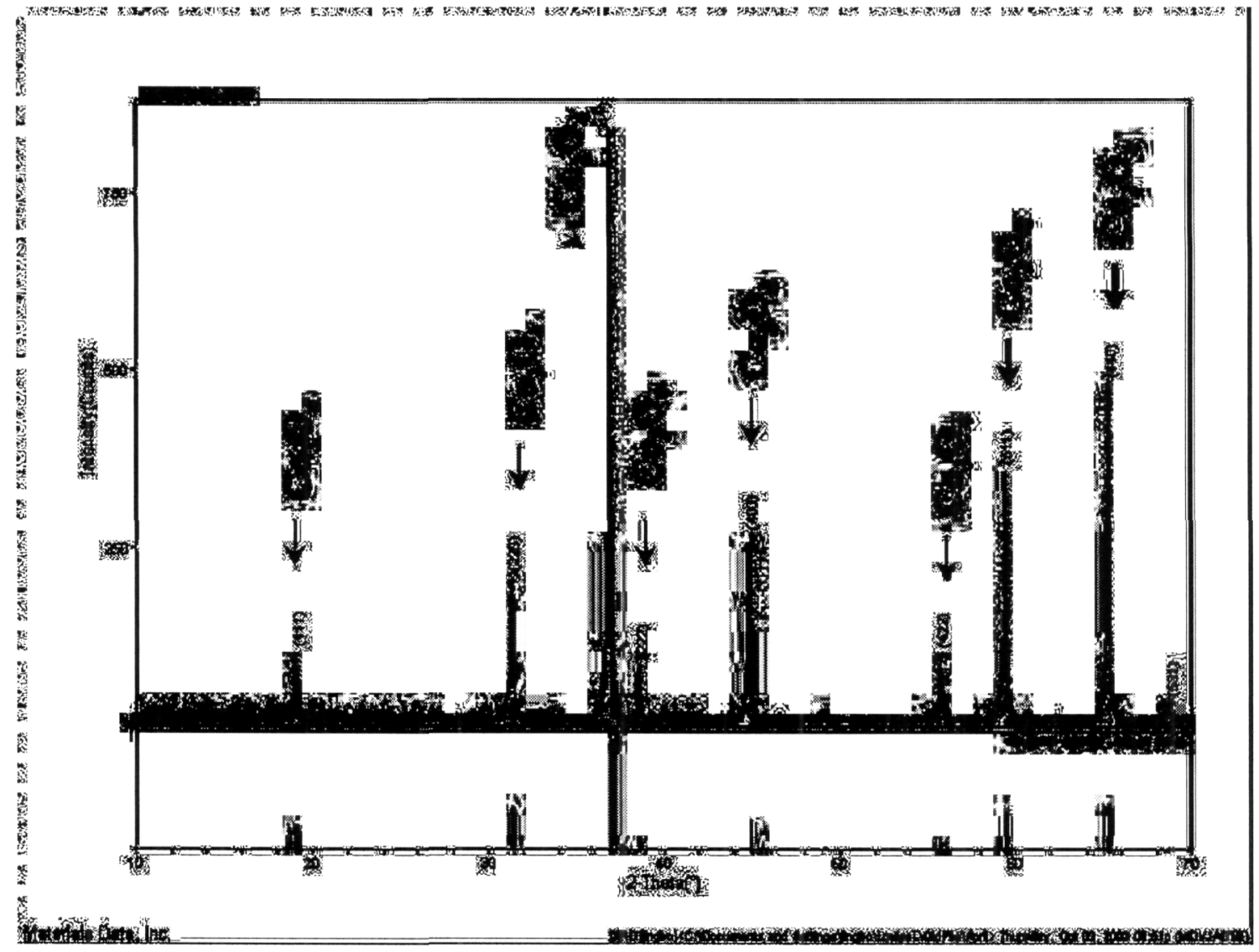

Figure 10 Powder XRD pattern of SGB dried at $300 \mathrm{C}$ for $2 \mathrm{~h}$

correspond to the Co $2 p_{3 / 2}$ and $2 p_{1 / 2}$ shell, respectively, while the peak at $530 \mathrm{eV}$ corresponds to the O $1 \mathrm{~s}$ shell.

The Co $2 p$ and O 1s XPS data for SGA and SGB films are essentially the same (Fig. 11), with the peaks at 781.3 and $797.2 \mathrm{eV}$ matching closely to the literature values for standard $\mathrm{CoO}[34,42,43]$. The presence of $\mathrm{CoO}$ was confirmed by the intense shake-up satellites ca. $6 \mathrm{eV}$ (observable after sputtering) above the primary spin-orbit BE [42] at 786.6 and $803 \mathrm{eV}$, corresponding to the $\mathrm{Co} 2 \mathrm{p}_{3 / 2}$ and $2 \mathrm{p}_{1 / 2}$ shake-up peaks. It is known in the literature [42] that the BE values of the most intense Co $2 p$ peak does not allow a clear distinction to be made between $\mathrm{CoO}$ (containing pure $\mathrm{Co}^{\mathrm{II}}$ ) and $\mathrm{Co}_{3} \mathrm{O}_{4}$ $\left(\mathrm{Co}^{\mathrm{II}} \mathrm{Co}_{2}^{\mathrm{III}} \mathrm{O}_{4}\right)$, due to the presence of the high-spin $\mathrm{Co}^{\mathrm{II}}$ in both cases. However, it is widely agreed that the presence of shake-up satellites, consistently observed in the literature, indicates the presence of $\mathrm{CoO}[43$, 44]. These satellites were used as a fingerprint for the identification of $\mathrm{Co}^{\mathrm{II}}$ species in $\mathrm{CoO}$.

Fig. 12, on the other hand, shows the Co $2 p$ XPS of the Co oxide SGB film formed at $300^{\circ} \mathrm{C}$ for $120 \mathrm{~min}$. The Co $2 p_{3 / 2}$ and $2 p_{1 / 2}$ peaks are at 780.3 and 795.7 $\mathrm{eV}$, respectively, again comparable to those reported in the literature for $\mathrm{CO}_{3} \mathrm{O}_{4}[34,42-44]$. In $\mathrm{Co}_{3} \mathrm{O}_{4}$, a single asymmetrical peak is sometimes observed, due to the contributions of the two oxidation states that are not very well resolved in the spectra. It is observed that $300^{\circ} \mathrm{C}$ dried films show very low intensity shake-up satellites, consistent with the literature XPS data for
$\mathrm{Co}_{3} \mathrm{O}_{4}$, for which the satellite peak is either very weak or is missing [34, 42-44].

Fig. 11 shows the $\mathrm{O} 1 \mathrm{~s}$ XPS spectrum of the $\mathrm{CoO}$ and $\mathrm{Co}_{3} \mathrm{O}_{4}$ reference standard and of the $150^{\circ} \mathrm{C}$ dried SGA and SGB films. O 1s XPS data for the $150^{\circ} \mathrm{C}$ dried films of SGA and SGB were again very similar. The main O $1 \mathrm{~s}$ peak is observed at $532 \mathrm{eV}$. A shoulder peak, which is more pronounced for the SGB film, is also observed at $532.9 \mathrm{eV}$. The literature attributes a binding energy ranging from $529.5-530.3 \mathrm{eV}$ to the $\mathrm{O}^{2-}$ ion in the crystalline network of $\mathrm{CoO}[42,44]$. The presence of non-equivalent hydroxy groups, low-coordinated oxygen ions at the surface, grain boundaries, defect sites and weakly adsorbed species at the surface has been assigned to the peaks at $531.5( \pm 0.2) \mathrm{eV}[34,42,43$, 45]. The peak at $530.1 \mathrm{eV}$ was specifically assigned by Borghi et al. [44] to surface adsorbed oxygen species that were later removed by sputtering. The peak at 533.3 $\mathrm{eV}$ has also been assigned previously to adsorbed water [42], or to the oxygen in retained nitrate species [35].

The $\mathrm{O}$ 1s binding energy observed for the cobalt oxide $\mathrm{SG}$ films shown at $532 \mathrm{eV}$ may be due to lowcoordinated oxygen ions $\left(\mathrm{O}^{2-}\right)$ at the surface, weakly adsorbed species, or contamination, as mentioned earlier. The shoulder observed at a higher BE of $532.9 \mathrm{eV}$ is very likely due to the presence of nitrate ions from the starting material, which is also seen in the XRD data. It is of interest that the lower BE O 1s peaks, indicative of $\mathrm{O}^{2-}$ in the $\mathrm{CoO}$ network, is not observed in the XPS 

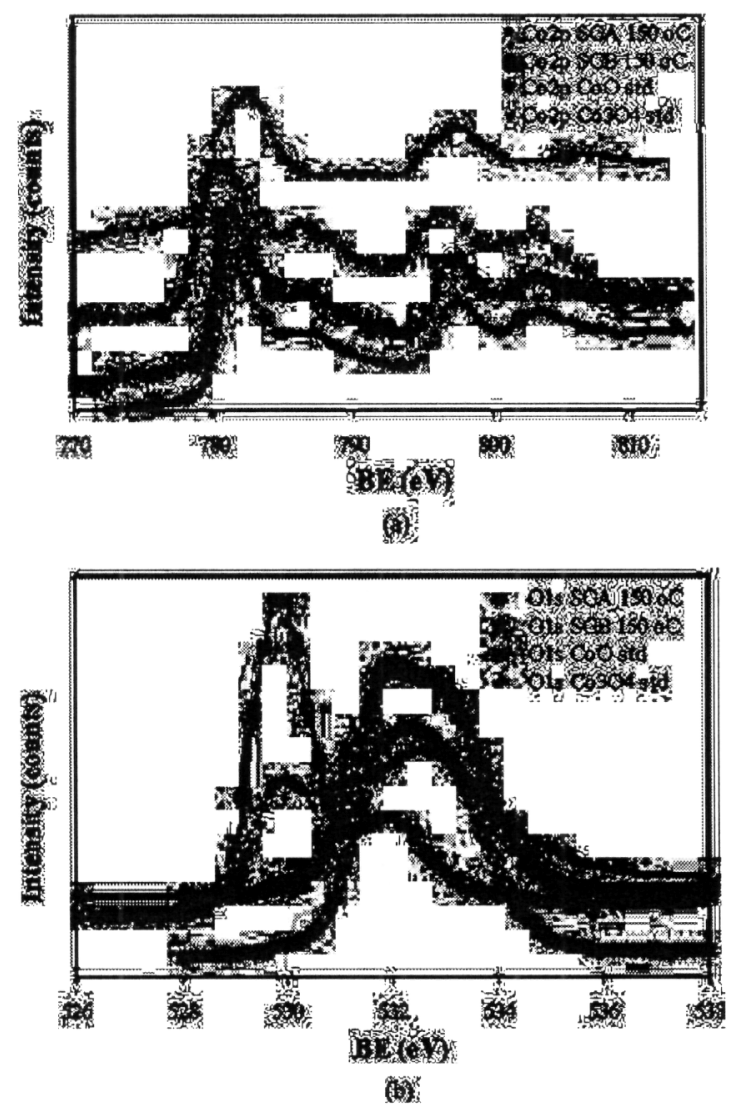

Figure 11 (a) $\mathrm{Co} 2 \mathrm{p}$ and (b) $\mathrm{O} 1 \mathrm{~s}$ XPS spectra for $\mathrm{CoO}$ and $\mathrm{CO}_{3} \mathrm{O}_{4}$ standards and SGA and SGB dried at $150 \mathrm{C}$ for $30 \mathrm{~min}$.

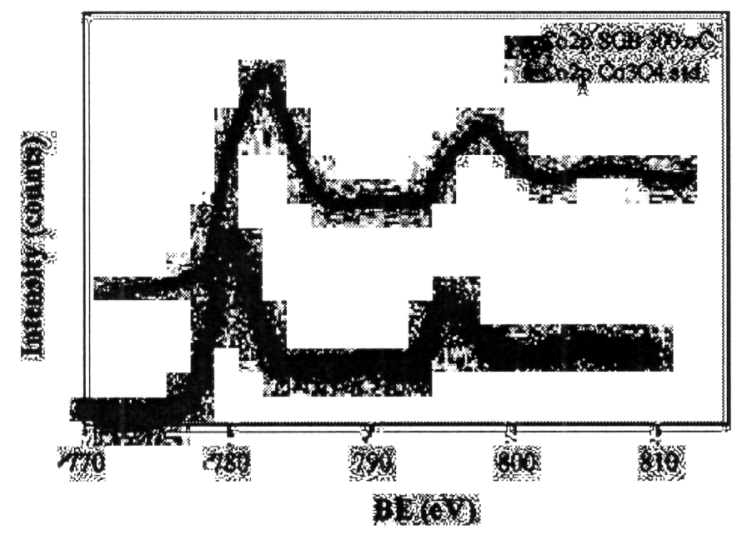

Figure $12 \mathrm{Co} 2 \mathrm{p}$ and XPS spectra for $\mathrm{CO}_{3} \mathrm{O}_{4}$ standard and $\mathrm{SGB}$ formed at $300 \mathrm{C}$ for $120 \mathrm{~min}$.

data collected for these SG films. This may be due to a surface contamination effect.

\subsection{Electrochemical behavior}

\subsubsection{Voltammetric analysis}

The electrochemical behavior of Co oxide in basic solution is relatively complex, due to the variety of oxidation states (0, I, II, III and IV) accessible between 0 and 1.6 V vs. RHE [21, 24]. Typical CVs, obtained for SGA (and SGB in inset) Co oxide films, dried at $175^{\circ} \mathrm{C}$, on $\mathrm{Pt}$ in $0.1 \mathrm{M} \mathrm{NaOH}$, are shown in Fig. 13. As reported by

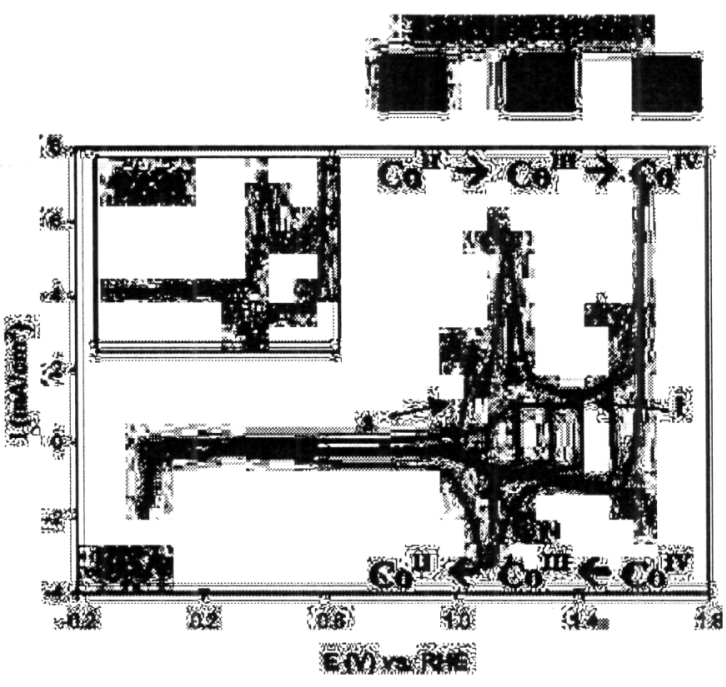

Figure 13 Cyclic voltammograms $(5 \mathrm{mV} / \mathrm{s})$ of $\mathrm{SGA}$ Co oxide film, formed at $6 \mathrm{~cm} / \mathrm{min}$ withdrawal rate, dried at $175 \mathrm{C}$ for $15 \mathrm{~min}$ (a), and then stabilized in $0.1 \mathrm{M} \mathrm{NaOH}$ for $18 \mathrm{~h}$ (b) before potential cycling at $5 \mathrm{mV} / \mathrm{s}$. Inset: $\mathrm{CV}(10 \mathrm{mV} / \mathrm{s})$ of SGB dried $175 \mathrm{C}$ for $120 \mathrm{~min}$.

Burke and others $[11,12]$ for electrochemically grown films on Co metal, the redox peaks $\left(\mathrm{A}_{0}, \mathrm{~A}_{1} / \mathrm{C}_{1}\right)$, centered at ca. 0.9 and $1.2 \mathrm{~V}$, are believed to be due to the conversion of $\mathrm{Co}$ (II) to $\mathrm{Co}(\mathrm{III})$-containing species, with suggested examples of the latter including $\mathrm{CO}_{2} \mathrm{O}_{3}$, $\mathrm{CO}_{3} \mathrm{O}_{4}\left(\mathrm{Co}^{\mathrm{II}} \mathrm{Co}_{2}^{\mathrm{III}} \mathrm{O}_{4}\right)$ and $\mathrm{CoOOH}[17]$. In fact, the $\mathrm{A}_{0}$ peak is frequently observed for SGA films, but rarely for SGB films. This may be related to the higher $A_{1} / C_{1}$ peak currents of SGB films (which are thicker), which consequently may obscure the $\mathrm{A}_{0}$ peak. A broad peak $\left(C_{1}\right)$ in the negative sweep, spread over the potential range of ca 0.8 to $0.3 \mathrm{~V}$, has been proposed to represent the reduction of $\mathrm{Co}$ (III) oxide to the $\mathrm{Co}$ (II) state. The $\mathrm{A}_{2} / \mathrm{C}_{2}$ peaks, centered at ca. $1.4 \mathrm{~V}$ and overlapping with the onset of oxygen evolution, have been suggested to be due to the $\mathrm{Co}$ (III)/Co(IV) oxide conversion process [21]. Electrochromic behavior was observed above and below ca. $1.2 \mathrm{~V}$, at the $\mathrm{Co}$ (II)/Co(III) transition for these low temperature films, at which point the film color changes between light brown and dark brown. The $\mathrm{Co}(\mathrm{III}) / \mathrm{Co}(\mathrm{IV})$ transition at $1.4 \mathrm{~V}$ however, causes the film to change between dark brown and black. For the higher temperature $\mathrm{CO}_{3} \mathrm{O}_{4}$ spinel electrode (Fig. 14), the $\mathrm{Co}$ (II)/Co(III) peaks are not observed. This observation may be due to the $1: 2 \mathrm{Co}$ (II): $\mathrm{Co}$ (III) ratio in the spinel structure. It has also been suggested in the literature [30] that the Co(II) sites may be less easily accessible due to their location in the tetrahedral site of the spinel structure, and thus the $\mathrm{Co}$ (II)/(III) redox transition cannot readily occur. Overall, the electrochromic behavior during the $\mathrm{Co}$ (III)/Co(IV) transition (i.e., from dark brown to black) can be difficult to differentiate, especially for thicker films.

The charge densities of the SG-derived Co oxide films were compared with those formed electrochemically at bulk Co metal. For a single dip Co oxide film, dried at $175^{\circ} \mathrm{C}$, charge densities were normally between 6 and $10 \mathrm{mC} / \mathrm{cm}^{2}$, and 50 and $70 \mathrm{mC} / \mathrm{cm}^{2}$, for SGA and SGB films, respectively. SG films dried at $300^{\circ} \mathrm{C}$ 


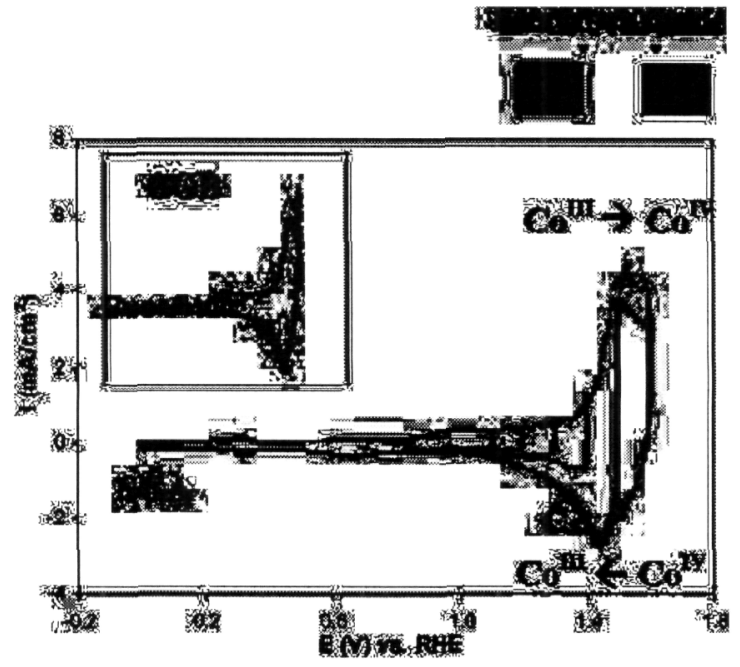

Figure 14 Cyclic voltammograms $(5 \mathrm{mV} / \mathrm{s})$ of $\mathrm{SGA}$ Co oxide film. formed at $6 \mathrm{~cm} / \mathrm{min}$ withdrawal rate, dried at $300 \mathrm{C}$ for $15 \mathrm{~min}$, and then stabilized in $0.1 \mathrm{M} \mathrm{NaOH}$ for $18 \mathrm{~h}$ before potential cycling at 5 $\mathrm{mV} / \mathrm{s}$. Inset: $\mathrm{CV}(10 \mathrm{mV} / \mathrm{s})$ of $\mathrm{SGB}$ formed identically, except dried at $300 \mathrm{C}$ for $120 \mathrm{~min}$.

showed smaller active charge densities, between 2 and $4 \mathrm{mC} / \mathrm{cm}^{2}$, and 10 to $20 \mathrm{mC} / \mathrm{cm}^{2}$, for SGA and SGB formed films, respectively, compared to the lower temperature dried films. For comparison, an electrochemically grown Co oxide film on a Co metal substrate showed a charge density from $5 \mathrm{mC} / \mathrm{cm}^{2}$ in the first hour of potential cycling between -0.5 and $+1.7 \mathrm{~V}$ vs. RHE at $1 \mathrm{~V} / \mathrm{s}$, to $8.5 \mathrm{mC} / \mathrm{cm}^{2}$ after $6 \mathrm{~h} \mathrm{[31].} \mathrm{Thus,}$ the $\mathrm{SG}$ route allows the more rapid formation of high charge density Co oxide films, as compared to other preparation techniques.

It is important to note that, while the literature on SG formed Co oxide films shows mainly the "high temperature" spinel CVs (Fig. 14), containing only one set of peaks between 1.2 and $1.4 \mathrm{~V}$ [9], our work has shown that the drying temperature is what defines the type of Co oxide made and the electrochemical response observed. In terms of their applications, lower temperature formed films will be more favored for electrochromic and supercapacitive applications, due to the more pronounced color change from the $\mathrm{Co}$ (II) to $\mathrm{Co}$ (III) transition and the broader, reversible $\mathrm{CV}$ response. On the other hand, the higher temperature formed films have more potential in battery applications. A comparison of the kinetics of the high vs. low temperature films will be discussed in a second paper [46], currently in preparation.

\subsubsection{Stability and reproducibility of $S G$ formed Co oxide films}

The stability of the CV response in base has been an inherent problem for SGA derived Co oxide films. Freshly formed films (Fig. 13 (curve a)) display a significant loss of the electrochemical signal (up to $50 \%$ ), particularly in the $A_{1} / C_{1}$ peak region prior to reaching a steady-state response (Fig. 13 (curve b)). The stability of SGA in basic solutions was improved by optimizing variables such as working in a less basic $0.1 \mathrm{M}$
$\mathrm{NaOH}$ solution, instead of $1 \mathrm{M} \mathrm{NaOH}$, pre-treating the film in the electrolyte for $18 \mathrm{~h}$ prior to electrochemical testing, and the use of the higher viscosity sol (SGB). Indeed, SGB Co oxide films have shown greatly improved stability, with only a ca. $10 \%$ loss in charge observed between the initial and the steady-state CV scans, and requiring only $2 \mathrm{~h}$ of pretreatment in $0.1 \mathrm{M}$ $\mathrm{NaOH}$. In some cases, it was observed that SG formed films showed an increase in charge within the first few scans prior to some loss in signal. It is believed that, in the initial scans, the dry SG film becomes wetted by the electrolyte solution [20, 24], thus providing improved access of counter ions $\left(\mathrm{Na}^{+}, \mathrm{OH}^{-}\right)$to the active sites within the film.

\section{Conclusions}

Nanoparticulate Co oxide films, of varying degrees of gelation/viscosity, were formed using the sol-gel (SG) synthesis method. A wide range of techniques were used to characterize the films and powders derived from this SG methodology. Transmission electron microscopy (TEM) images have shown pseudo-spherical particles, increasing in size with drying temperature and independent of the original gel viscosity. These particles are typically below $20 \mathrm{~nm}$ in size, even when the films were dried at high temperatures of $\sim 600^{\circ} \mathrm{C}$. In addition, a narrow particle size distribution is generally observed for any one set of preparation conditions.

Thermal gravimetric analysis (TGA), differential scanning calorimetry (DSC), powder X-ray diffraction (XRD), electron diffraction (ED) and X-ray photoelectron spectroscopy (XPS) data confirm the formation of two different Co oxide materials when the sol-gels are dried below and above the transition temperature of $\sim 200^{\circ} \mathrm{C}$. Results suggest the presence of primarily $\mathrm{CoO}$, possibly some $\mathrm{Co}\left(\mathrm{NO}_{3}\right)_{2}$ starting material, and trace amounts of $\mathrm{Co}_{3} \mathrm{O}_{4}$ for $\mathrm{SG}$ films and powders formed at $<200^{\circ} \mathrm{C}$, while films dried at $>200^{\circ} \mathrm{C}$ are undoubtedly converted to a $\mathrm{Co}_{3} \mathrm{O}_{4}$ spinel structure. Two distinct electrochemical signatures were observed in $0.1 \mathrm{M} \mathrm{NaOH}$ solutions for these two different types of Co oxide films. For films formed at the lower temperatures, the cyclic voltammograms show two pairs of peaks attributed to the $\mathrm{Co}$ (II) to $\mathrm{Co}(\mathrm{III})$ transition at 1.2 $\mathrm{V}$ and the Co(III) to Co(IV) transition at $1.4 \mathrm{~V}$, whereas the higher temperature formed films showed only the $\mathrm{Co}$ (III) to $\mathrm{Co}$ (IV) transition at $1.4 \mathrm{~V}$. It is suggested that the absence of the peaks at $1.2 \mathrm{~V}$ for the higher temperature films may be due to the less accessible $\mathrm{Co}$ (II) tetrahedral sites, and thus no redox activity from these sites is observed [30].

The highly viscous SGB led to an improved film stability in alkaline solutions, especially for the lower temperature films. The charge density obtained for a single coat of the SGB precursor ranges from 50 to $70 \mathrm{mC} / \mathrm{cm}^{2}$ for Co oxide films dried at $175^{\circ} \mathrm{C}$ for $120 \mathrm{~min}$ and 10 to $20 \mathrm{mC} / \mathrm{cm}^{2}$ for films dried at $300^{\circ} \mathrm{C}$ for $120 \mathrm{~min}$.

\section{Acknowledgements}

We would like to acknowledge overall financial support from the Natural Sciences and Engineering Research 
Council of Canada (NSERC). We would also like to thank Professor Wang Zhimin from the University of Heilongjiang (China) for useful discussions of our XRD data, Dr. Dimitre Karpuzov from the Alberta Centre for Surface Engineering and Science (ACSES) at the University of Alberta for valuable assistance with XPS analysis, Dr. Boris Dymov from the University of Calgary for help with early SEM/TEM work, Robert Marr from the University of Calgary for help with the electron microprobe, and also Professor George Shimizu and Dr. Adrien Cote for their assistance with the TGA/DSC instrument.

\section{References}

1. K. TAKADA, N. AOTANI, K. IWAMOTO and S. KONDO, Solid State Ion. 79 (1995) 284.

2. S. P. SHEU, C. Y. YAO, J. M. CHEN and Y. C. CHIOU, J. Power Sour: 68 (1997) 533.

3. G. TING-KUO FEY, V. SUBRAMANIAN and J.-G. CHEN, Electrochem. Commun. 3 (2001) 234

4. N. ÖZER, D.-G. CHEN and T. B Ü Y Ü KLIMANLI, Solar Energy Mater. and Solar Cells 52 (1998) 223.

5. L. D. KADAM and P. S. PAT1L, ibid. 70 (2001) 15.

6. E. POTVIN and L. BROSSARD, J. Appl. Electrochem. 25 (1995) 462.

7. V. RASHKOVA, S. KITOVA, I. KONSTANTINOV and T. VITANOV, Electrochim. Acta 47 (2002) 1555

8. C. K. KIM, Mater. Sci. Engng. B 40 (1996) 72.

9. C. LIN, J. A. RITTER and B. N. POPOV, J. Electrochem. Soc. 145 (1998) 4097.

10. S. I. CORDOBA-TORRESI, C. GABRIELLI, A. HUGOT-LE GOFF and R. TORRESI, ibid. 138 (1991) 1548.

11. L. D. BURKE and M. M. MURPHY, ibid. 138 (1991) 88.

12. R. P. SIMPRAGA.J. Electroanal. Chem. 355 (1993) 79.

13. A. AGRAWAI, H. R. HABIBI, R. K. AGRAWAL, J. P. CRONIN, D. M. ROBERTS, R. CARON-POPOWICH and C. M. LAMPERT, Thin Solid Films 221 (1992) 239.

14. K. W. KIM, S. I. WOO, K.-H. CHOI, K. -S. HAN and Y. - J. PAR K, Solid State Ion. 159 (2003) 25.

15. C. A. MAROZZI and A. C. CHIAL VO, Electrochimica Acta, 45 (2000) 2111.

16. R. N. SINGH, J. KOENIG, G. POILERAT and P. CHARTIER, J. Electrochem. Soc. 137 (1990) 1408.

17. F. Š VEGL, B. OREL, M. G. HUTCHINS and K. KALCHER, ibid. 143 (1996) 1532.

18. F. Š WGil, B. OREL and M. G. HUTCHINS, J. Sol-Gel Sci. Tech. 8 (1997) 765.

19. F. ŠVEGL, B. OREL, I. GRABEC- ك̌ VEGL and V. K A UCIC, Electrochim. Acta 45 (2000) 4359.

20. 1. SEREBRENNIKOVA and V. I. BIRSS, J. Electroanal. Chem. 493 (2000) 108.

21. G. SPINOLO, S. ARDIZZONE and S. TRASATTI, ibid. 423 (1997) 49 .
22. E. BARRERA, T. VIVEROS, A. AVIIA, P. QUINTANA, M. MORAIES and N. BATINA, Thin Solid Films 346 (1999) 138.

23. H. TOTOTZINTI.E-HUITLE, E. PROKHOROV, A. MENDOZA-GALVÁN, J. E. URBINA andJ. GONZÁLEZHER Ná NDEZ7. J. Phis. Chem. Solids 64 (2003) 975.

24. I. SEREBRENNIKOVA and V. I. BIRSS, J. Electrochem. Soc. $147(2000) 3614$.

25. K. S. ALBER and J. A. COX, Milkrochimica Acta 127 (1997) 131.

26. O. LEV and $Z$. WU, Chem. Mater: 9 (1997) 2354.

27. C. J. BRINKER and (i. W. SCHERER, "Sol-Gel Science: The Physics and Chemistry of Sol-Gel Processing" (Academic Press Inc., New York, 1990).

28. I. SEREBRENNIK OV A and V. I. BIRSS, J. Electrochem. Soc 144 (1997) 565.

29. Idem., J. Mater. Sci. 36 (2001) 4331 .

30. I. SEREBREnNikova. Ph.D. Thesis, Department of Chemistry, University of Calgary, Canada (1999).

31. A. CO, Undergraduate Thesis, Department of Chemistry, University of Calgary, Canada (1999).

32. F. H. MOSER and N. R. I.YNAM, U.S. Patent 4,959,247 (1990).

33. H. P. KLUG and L. E. ALEXANDER, "X-ray Diffraction Procedures" (John Wiley and Sons, New York, 1962).

34. M. M. Natile and A. Glisenti, Chem. Mater. 15 (2003) 2502

35. J. F. MOUIDER, W. F. STICKLE, P. E. SOBOL and K. D. BOMBEN, in "Handbook of X-ray Photoelectron Spectroscopy" (Perkin-Elmer Corporation, Eden Prairie, Minnesota, 1992) p. 8.

36. Y. YAO and A. THÖILÉN, Nanotechnology 13 (2002) 169

37. Y. JIANG, Y. WU, B. XIE, Y. XIE and Y. QIAN, Mater. Chem. Phys. 74 (2002) 234

38. X. SHI, S. HAN, R. J. SANEDRIN, F, ZHOU and M. SEL KE, Chem. Mater. 14 (2002) 1897.

39. N. S. WhEeler, J. Res Natl. Inst. Stand. Technol. 100 (1995) 641 .

40. J. M. THOMAS and W. J. THOMAS, "Principles and Practice of Heterogeneous Catalysis" (VCH, New York, 1997) p. 152.

41. A. C. ThOMpson and D. VAUGHAN, "X-Ray Data Booklet" (Lawrence Berkeley National Laboratory, Berkeley, Califormia, 2001).

42. D. BARRECA, C. MASSIGNAN, S. DAOLIO, M. FABRIZIO, C. PICCIRILLO, L. ARMELAO and E. TONDEllo, Chem. Mater. 13 (2001) 588.

43. M. M. NATILE and A. GLISENTI, ibid. 14 (2002) 3090.

44. A. BORGHI, A. DI BONA, D. BISERO and S. VALERI, Appl. Surf. Sci. 150 (1999) 13.

45. R. DEDRYVERE, S. GRUGEON, S. LARUEILE, P. POIZOT, D. GONBEAU and J.-M. TARASCON, LiBD 2003-Electrode Materials (2003) Abstract no. 68.

46. A. CO, J, LIU and V. I. BIRSS (2004) in preparation.

Received 20 February 2004

and accepted 16 February 2005 